Egyptian Journal of Aquatic Biology \& Fisheries

Zoology Department, Faculty of Science,

Ain Shams University, Cairo, Egypt.

ISSN 1110 - 6131

Vol. 22(5): 137- 148 (2018)

www.ejabf.journals.ekb.eg

\title{
Histological and ultrastructural alternations in the digestive gland of the \\ Egyptian slug, Limax maximus (Linnaeus, 1758) treated with botanic molluscicidal thymol, with reference to biological studies
}

\author{
Ustina N. T. Habib*; Ahmed A. Abdel-Haleem; Omaima M. Mustafa and \\ Eman H. Ismail. \\ Department of Biological and Geological Sciences, Faculty of Education \\ Ain Shams University, Cairo, Egypt. \\ *Corresponding author: ustina.habib@ gmail.com
}

\section{ARTICLE INFO}

Article History:

Received:Sept.17,2018

Accepted:Oct. 29, 2018

Available online:Nov.2018

Keywords:

Limax maximus

Egyptian garden slug

digestive gland

thymol

Histology

Cytology

\begin{abstract}
The present work included biological studies, morphological and anatomical features, beside histological and ultrastructural alternations due to effects of the botanical thymol, as poison bait, on the digestive gland of the Egyptian giant garden slug, Limax maximus (Family: Limacidae) after treating it with $\mathrm{LC}_{50}$ and $\mathrm{LC}_{90}$ for $48 \mathrm{hrs}$. Thymol is considered as a botanic molluscicidal mono-terpenoid, that is found in several plants. The estimated value of $\mathrm{LC}_{50}$ and $\mathrm{LC}_{90}$ of thymol are 269.77 and $362.79 \mathrm{ppm}$ respectively. The effect of $\mathrm{LC}_{90}$ on the digestive gland caused severe histological changes and ultrastructural abnormalities; as: cytoplasmic vacuolation, scattered toxic agents, degeneration of some nuclei and cells, rupture of microvilli, increasing of calcium spherules inside secretory cells and wide-fused vacuoles. So, thymol may be of great value in the field to control the target slug, as safe and economic molluscicide, which no harm upon ecosystems instead of using chemical pesticides that could pollute the environment.
\end{abstract}

\section{INTRODUCTION}

The giant garden slug, Limax maximus (Family: Limacidae) has a natural Western Palearctic distribution, but had been introduced into North and South America, South Africa, some Pacific Islands, Australia and New Zealand and many places in the world (Herbert, 2010).

In Egypt, few studies had been achieved on the slug L. maximus by El-okda (1980) in Alexandria and Beheira, Azzam (1995) in several Egyptian governorates and Beltagi, et al. (2016) in Al-Galubeiah, Egypt.

The slugs considered a crop pest, where they destroy fruit trees, vegetables and ornamental plants. Thus, they cause serious reduction in the yield production of crops and fruits, beside destroying plant seedlings (El-okda, 1980). The mucus from the slug activity is also known to accelerate nutrient cycling and used for treatment of skin warts and wounds (Thomas, 2013). In addition, it is used as slug syrup to cure cough and bronchitis. (Mustafa, 2001).

In contrast, synthetic chemical molluscicides had a toxic effects on non-target organisms, where they contaminate soil and water and may consequently affect local populations of humans and other animals (Thiengo et al., 2005). 
The molluscicidal plants have many advantages as: low toxicity effect to nontarget organisms, biodegradable, not expensive and more safely to the environment (Abdel-Haleem, 2013).

Thymol is mono-terpenoid found in a wide variety of plants: from which Thymus vulgaris L. and Origanum vulgare (Grodnitzky and Coast, 2002). It has been shown to possess remarkable molluscicidal activity against Lymnaea acuminate (Singh and Singh, 2000), the land snail Helix aspersa (El-Zemity, et al., 2001); land snail Subulina octona (Ferreira, et al., 2009) slugs Arion lusitanicus and Deroceras reticulatum (Kozlowski and Kozlowski, 2007) insecticidal activity (Pavela and Sedlák, 2018) and antibacterial activity (Sokolik, et al., 2018).

The present studies aim to describe the external and internal features, through morphological and anatomical studies, on the slug. In addition, examination of the histological and ultrastructural effects of the thymol in cell-types of the digestive gland of the treated slug, after treatment with $\mathrm{LC}_{50}$ and $\mathrm{LC}_{90}$ of thymol compound.

\section{MATERIALS AND METHODS}

\section{Biological studies:}

Morphology:

Adult slug Limax maximus had been examined under binuclear to examine, photographed and diagrammatically draw details of morphological features of it.

\section{Anatomy:}

Adult slug L. maximus had been dissected under binuclear to examine, photographed and draw diagrammatic representation of the details of internal organs of it.

\section{Experimental animals}

The slugs L. maximus were acclimatized under laboratory conditions before being used in the experimental tests for $48 \mathrm{hrs}$. Adult slug had been collected from the garden of Faculty of Education, Ain Shams University, Cairo, Egypt. They kept in transparent plastic storage boxes containing humid soil, $3 \mathrm{~cm}$ depth, in the laboratory and covered with muslin cloth. Slugs were daily fed with fresh lettuce leaves and water were added to provide suitable humidity for slug activity and the continuous cleaning of the boxes achieved.

\section{Thymol product:}

The plant product used as molluscicide in the present work is thymol, that purchased from El Gomhoureya co. as following:

\section{Molecular Formula: $\quad \mathrm{C}_{10} \mathrm{H}_{14} \mathrm{O}$.}

Molecular Weight: $\quad 150.221 \mathrm{~g} / \mathrm{mol}$.

Chemical structure:<smiles>Cc1ccc(C(C)C)c(O)c1</smiles>

\section{Experimental preparations:}

Prepared concentrations, 200, 250, 300, 350, $400 \mathrm{ppm}$ of thymol had been mixed with molasses and wheat-bran in 250 ml-plastic cups, to obtain poison bait. Controls (un-treated slugs) were prepared with the same procedure without adding poison baits. Then, slugs examined daily for $48 \mathrm{hrs}$. Dead individuals were counted and removed. Mortality percentages were recorded (48 hrs. post-treatment). 
To estimate $\mathrm{LC}_{50} \& \mathrm{LC}_{90}$ of thymol, the experimental samples were divided into three groups (10 slugs/cage per each) as follows:

Group 1: Control (untreated) slugs.

Group 2: Treated slugs with $\mathrm{LC}_{50}$.

Group 3: Treated slugs with $\mathrm{LC}_{90}$.

Finally, this experiment had been repeated four times and the mean of the estimated data obtained.

Bioassay:

The values of $\mathrm{LC}_{50}$ and $\mathrm{LC}_{90}$ of thymol were calculated according to the method of Litchfield and Wilcoxon (1949). The percentage of the mortality were recorded after $48 \mathrm{hrs}$. $\mathrm{LC}_{50}$ and $\mathrm{LC}_{90}$ for thymol were determined by the probit analysis method according to Finney (1971).

\section{Histological preparation:}

Alive slugs from control and treated experiments were dissected and digestive glands were immediately excised and cut into small pieces. These specimens were fixed in aqueous bouin's fixative for $24 \mathrm{hrs}$, then kept in a mixture of $70 \%$ ethanol and glycerol (95:5). Then dehydration achieved through an ascending series of ethanol followed by clearing in terpineol for three days, washed in benzene and embedded in paraffin wax. Sections, $6 \mu \mathrm{m}$ thick, were prepared, mounted on clean glass-slides and stained with Ehrlich's acid alum haematoxylin and counter stained by Eosin. Finally, the slides were examined and photographed using light microscope (Olympus CX31) connected with digital camera (model No. E -330) at central lab., Faculty of Education, Ain Shams University.

\section{Ultrastructural preparation:}

Control and treated slugs were anesthetized with $30 \%$ ethyl alcohol/ chloroform and dissected to obtain the digestive gland. Dissected glands were cut into small pieces, fixed with $2.5 \%$ paraformaldehyde-3\% glutaraldehyde ( $\mathrm{pH}$ 6.7) at room temperature for four hours, post-fixed with $(1 \%)$ phosphate buffered $\mathrm{OsO}_{4}(15$ minutes) and the specimens were rinsed in $0.2 \mathrm{M}$ phosphate buffer ( $\mathrm{pH} 7.3$ ), finally specimens were dehydrated in ethyl alcohol and embedded in Epon 812 mixture. Then, semi-thin sections were obtained with LKB-V ultramicrotome and stained with uranyl acetate and lead citrate. Finally, prepared sections were examined under TEM (JEM 100CX-II, 80kV) at the Regional center of Mycology and Biotechnology (RCMB), Al-Azhar University.

\section{RESULTS}

\section{Biological studies: \\ Morphology:}

The slug Limax maximus is belonging to family Limacidae. Its measures are 10$20 \mathrm{~cm}$ in length and is generally light grey or grey-brown colored with darker spots and blotches and characterized by short keel. The head occupies the anterior region and has the mouth opening on its front surface and dorsally bears two pairs of sensory tentacles. The $1^{\text {st }}$ anterior pair of tentacles is olfactory in function and relatively short, whereas the posterior $2^{\text {nd }}$ pair of tentacles is optical in function, relatively longer than the $1^{\text {st }}$ one and has terminal black eye-spot. The slug has internal short shell. Pneumostome is situated at the right side of the mantle. Foot is a muscular organ, creamy white in color and secretes colorless mucus (Fig. 1, a \& b). 

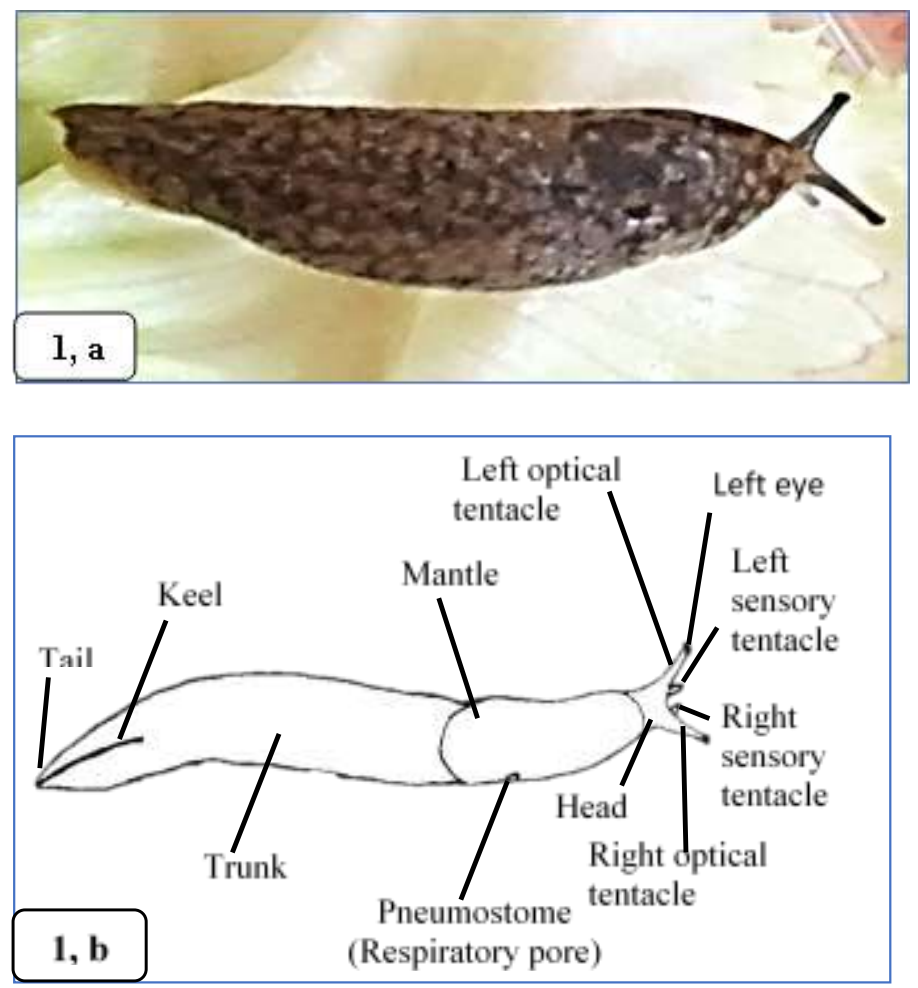

Fig. 1: A photograph of L. maximus showing external features (a) and a diagrammatic drawing of external feature of the slug (b).

\section{Anatomy:}

After being dissected, the slug $L$. maximus showed buccal mass leads to esophagus continuing through crop, stomach to three loops of intestinal canal leading into rectum and finally the anus.

There are right and left salivary glands, each has salivary duct. Digestive gland is formed of two large lobed-digestive caeca, darkly brown in color and connected with the stomach and intestine. The internal organs of the reproductive system include dark brownish ovotestis which located in the posterior end of the haemocoel followed by duct of ovotestis, albumen gland, fertilization chamber, male channel, female channel and penis (Fig. 2, a \& b).
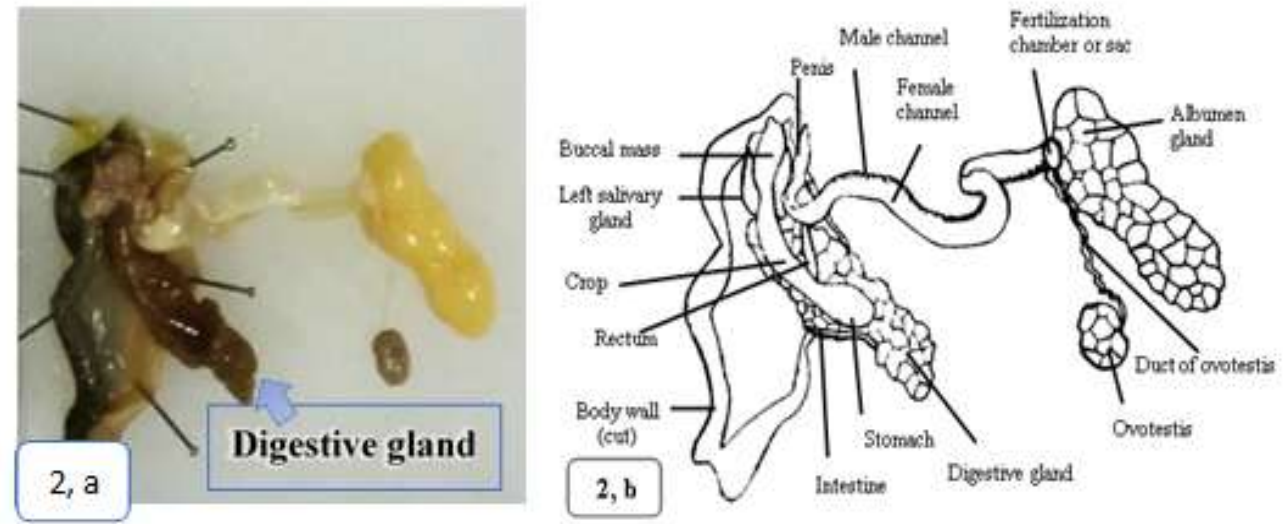

Fig. 2: A photograph of a dissected untreated specimen of L. maximus (a) and a diagrammatic drawing of the internal organs (b). 


\section{Bioassay:}

The resulted estimated values of $\mathrm{LC}_{50}$ and $\mathrm{LC}_{90}$ obtained from the susceptibility test of the thymol against L. maximus were $269.77 \mathrm{ppm}$ and $362.79 \mathrm{ppm}$ respectively, as described in Table (1) and Figure (3).

Table 1: Molluscicidal activity of thymol against the slug Limax maximus, after 48 hours of treatment.

\begin{tabular}{|c|c|c|c|}
\hline Concentration & Dead/total & Observed mortality $\%$ & Expected mortality \% \\
\hline Control & $0 / 20$ & 0 & - \\
\hline 200 & $4 / 20$ & 20 & 14.5152 \\
\hline 250 & $6 / 20$ & 30 & 43.5881 \\
\hline 300 & $16 / 20$ & 80 & 71.6006 \\
\hline 350 & $17 / 20$ & 85 & 88.3056 \\
\hline 400 & $\begin{array}{c}20 \\
(19.5) / 20\end{array}$ & 100 & 95.7776 \\
\hline \multicolumn{2}{|c|}{ Slope } & \multicolumn{2}{|c|}{$9.2490+/-1.6107$} \\
\hline \multicolumn{2}{|c|}{$x^{2}$} & \multicolumn{2}{|c|}{3.0562} \\
\hline \multicolumn{2}{|c|}{$\mathrm{LC}_{50}$} & \multicolumn{2}{|c|}{269.77} \\
\hline \multicolumn{2}{|c|}{$\mathrm{LC}_{90}$} & \multicolumn{2}{|c|}{362.79} \\
\hline
\end{tabular}

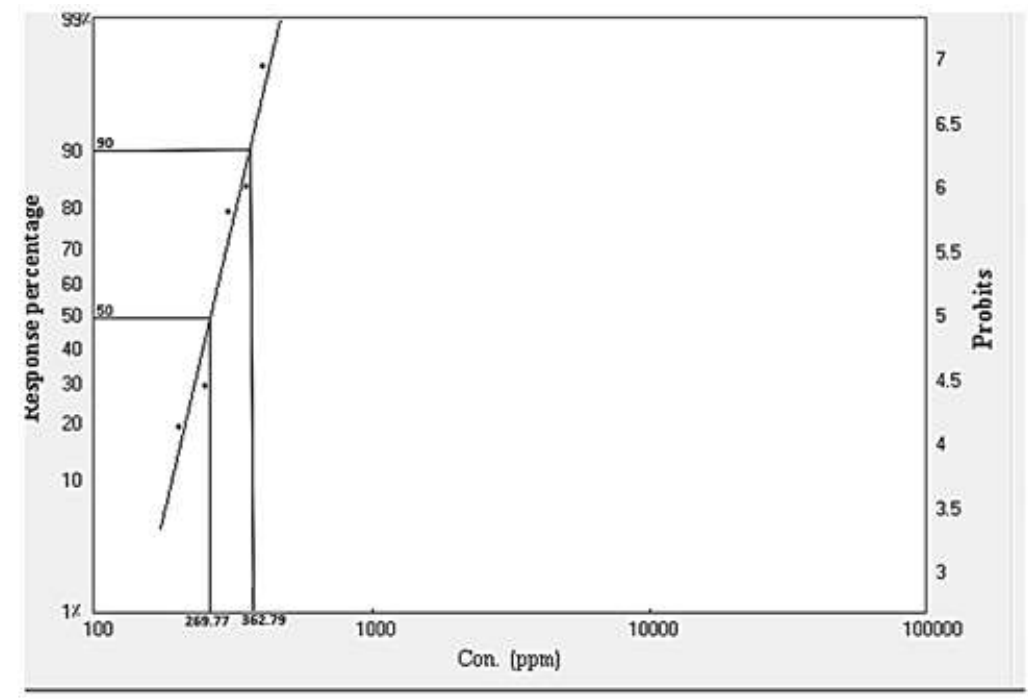

Fig. 3: Regression mortality line of the treated slug Limax maximus with different concentrations of thymol.

\section{Histological and ultrastructural studies of digestive gland: Histological examination:}

The digestive gland of L. maximus composed of columnar epithelial cells; named digestive and secretory cells arranged around a central lumen. These cells rested on a basement membrane (Fig. 4). Digestive cells are simple columnar cells with round apices and narrow bases. They are characterized by several vesicles of different sizes and elliptical or irregular basal nucleus (Fig. 5). On the other hand, secretory cell is pyramidal or conical-shaped with broad bases and pointed apices. Their nucleus is spherical in shape, basophilic and basal (Fig. 6).

Examination of the digestive gland of treated slugs with $\mathrm{LC}_{50}$ of thymol showed slight histological changes in the two cell- types whereas $\mathrm{LC}_{90}$ revealed severe histological changes, including: vacuolated cytoplasm (Figs. 7-11), some degenerated cells of digestive and secretory cells (Figs. 7\&8), abnormal star-shaped and 
degenerated nuclei (Figs. 8, $9 \& 11$ ) as well as some pale toxic agents inside the cells (Fig. 7) and in the lumen.
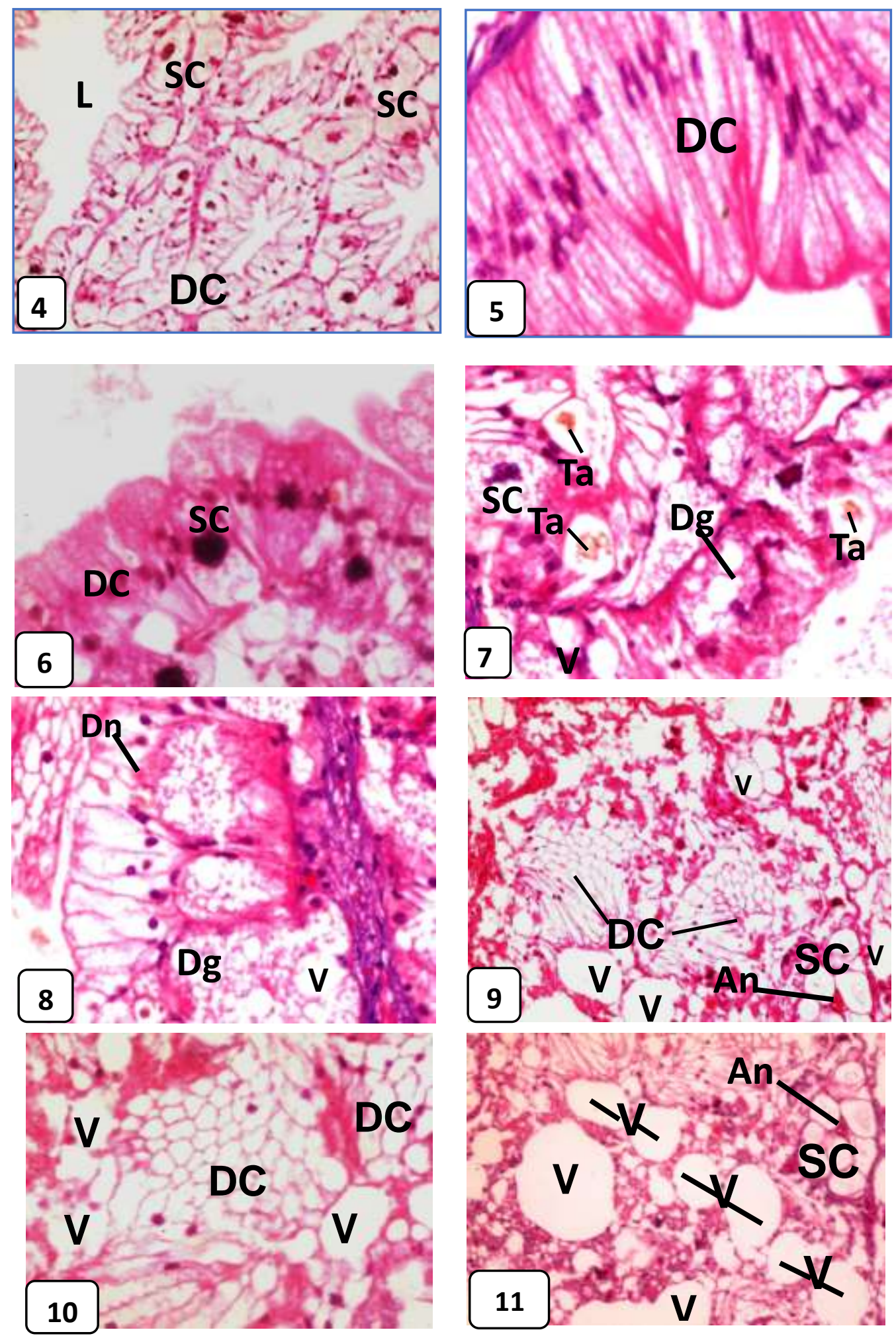

Plate 1: Photomicrographs of digestive gland of L. maximus stained with H\&E. Figs. 4-6: untreated group showing digestive cells (DC), secretory cell (SC) and lumen (L). Figs. 7\&8: treated group with $\mathrm{LC}_{50}$ of thymol for $48 \mathrm{hrs}$. showing vacuoles (V) inside digestive cells (DC) and secretory cells (SC), degenerated cells ( $\mathrm{Dg}$ ) beside some toxic agent (Ta) and degenerated nucleus (Dn). Figs. 9-11: treated group with $\mathrm{LC}_{90}$ of thymol for $48 \mathrm{hrs}$. showing vacuoles (V), digestive cells (DC), secretory cells (SC) and abnormal star-shaped nucleus (An). (Figs. 4,7\&9) $(\mathrm{X}=400)$ and (Figs. 5,6, 8, $10 \& 11)(\mathrm{X}=1000)$. 


\section{Ultrastructural examination:}

Examination of digestive gland of $L$. maximus by TEM revealed that digestive gland consists of the two cells, named secretory and digestive. These cells are simple columnar epithelial cells and their finger-like projected microvilli present apically, that may be simple, facing the lumen. Pinocytotic vesicles of various dimensions revealed in the apical cytoplasm of the digestive cell whereas calcium spherules in the secretory cell detected (Fig. 12). The nucleus is basal and spherical or elliptical or irregular in shape surrounded by rough endoplasmic reticulum and mitochondria (Fig. 13).
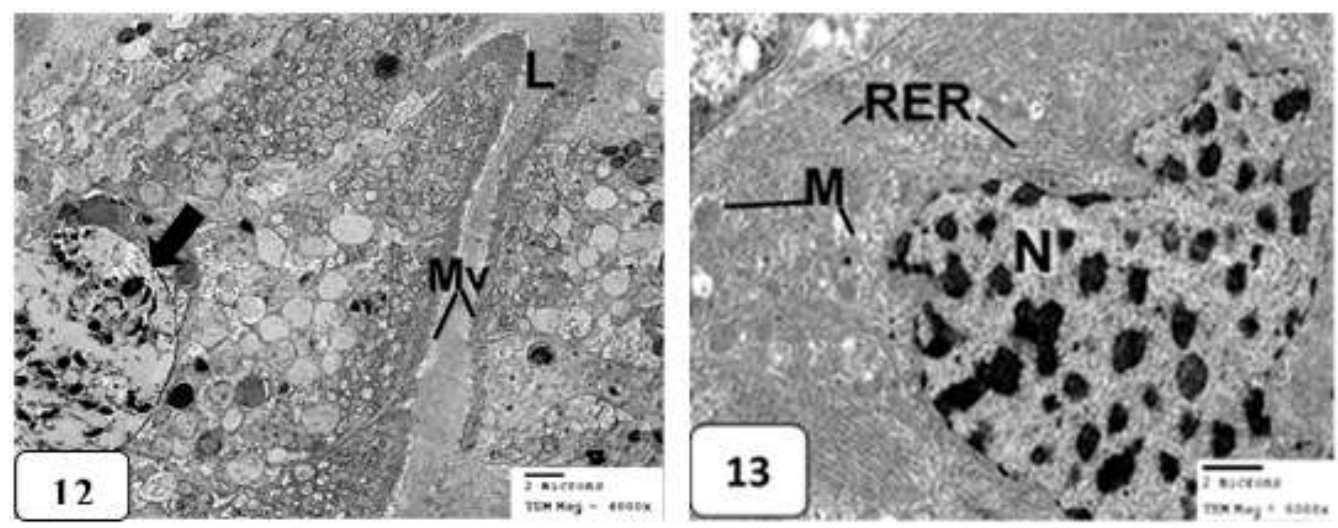

Figs. 12\&13: TEM of sections in the digestive cells of untreated L. maximus.

Fig. 12: Illustrating digestive lobule open in the lumen $(\mathrm{L})$, microvilli $(\mathrm{Mv})$ are observed at the apical part of digestive and secretory cells, calcium spherules in the secretory cell (black arrows) $(\mathrm{X}=4000)$. Fig. 13: Revealing the digestive cell-nucleus $(\mathrm{N})$, rough endoplasmic reticulum (RER) near the nucleus and mitochondria $(\mathrm{M})(\mathrm{X}=6000)$.

Fine structural micrograph of digestive gland of the treated slugs with $\mathrm{LC}_{50}$ and $\mathrm{LC}_{90}$ thymol for $48 \mathrm{hrs}$. showed many alternations in digestive gland, increased with $\mathrm{LC}_{90}$, as compared with untreated samples. This changes include: various cellular vacuoles in varied sizes inside the cells (Figs. 14-19, $21 \& 22$ ), degeneration of some cells (Figs. 14 \& 17), degenerated mitochondria and RER (Fig. 15), ruptured microvilli (Fig. 18 \& 21), abnormal nucleus (Fig. 16) scattered toxic agent (Fig.16 \& 22), degenerated-extracellular matrix (Fig.19), accumulation of calcium spherules in secretory cells (Fig. 16) and nearly necrosis of the two types of cells (Figs. $18 \& 20$ 22).
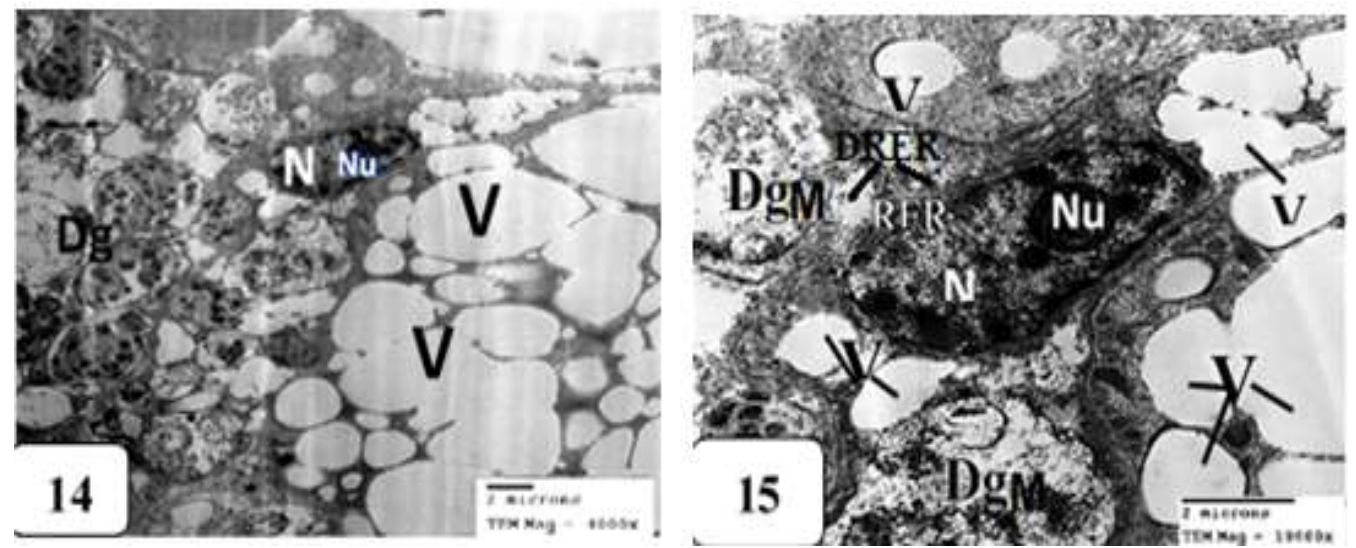

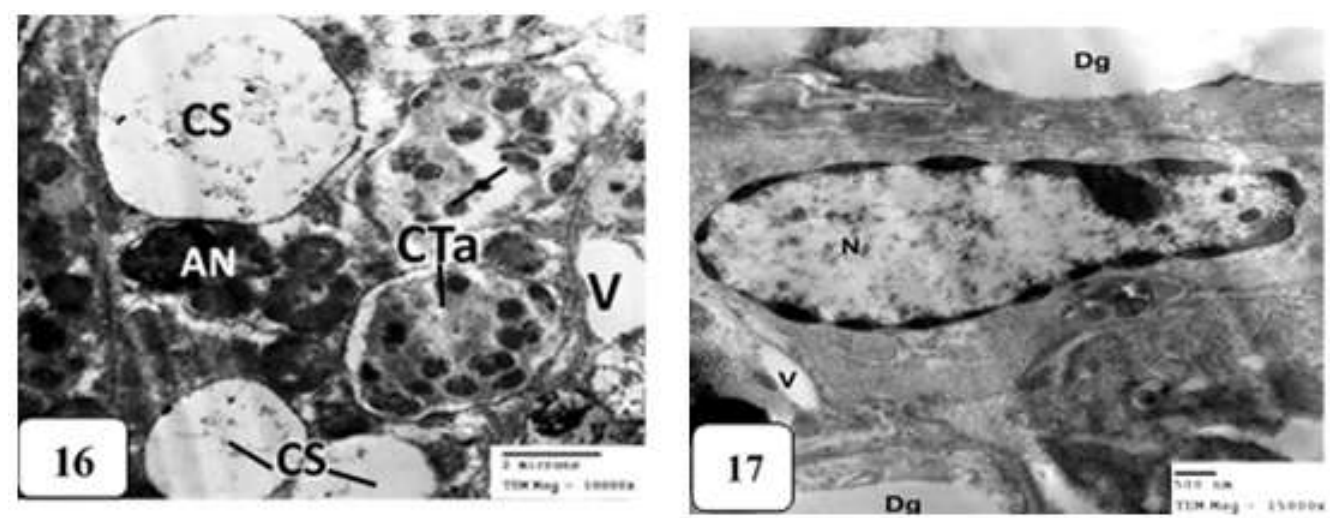

Figures 14-17: TEM of sections in the digestive gland of treated L. maximus with $\mathrm{LC}_{50}$ of thymol for $48 \mathrm{hrs}$.

Fig. 14: Showing nucleus $(\mathrm{N})$, nucleolus $(\mathrm{Nu})$, vacuoles $(\mathrm{V})$ and degenerated cell $(\mathrm{Dg})(\mathrm{X}=4000)$. Fig. 15: revealing nucleus $(\mathrm{N})$, nucleolus $(\mathrm{Nu})$, vacuoles $(\mathrm{V})$, degenerated-rough endoplasmic reticulum (DRER) and degenerated mitochondria $(\mathrm{DgM})(\mathrm{X}=10000)$. Fig. 16: Illustrating vacuoles $(\mathrm{V})$ abnormal nucleus (AN), numerous calcium spherules (CS) and cysts of numerous toxic agents (CTa). $(\mathrm{X}=10000)$. Fig. 17: Showing intratubular connective tissue, nucleus $(\mathrm{N})$, small vacuoles $(\mathrm{V})$ and degenerated cell $(\mathrm{Dg})(\mathrm{X}=15000)$.

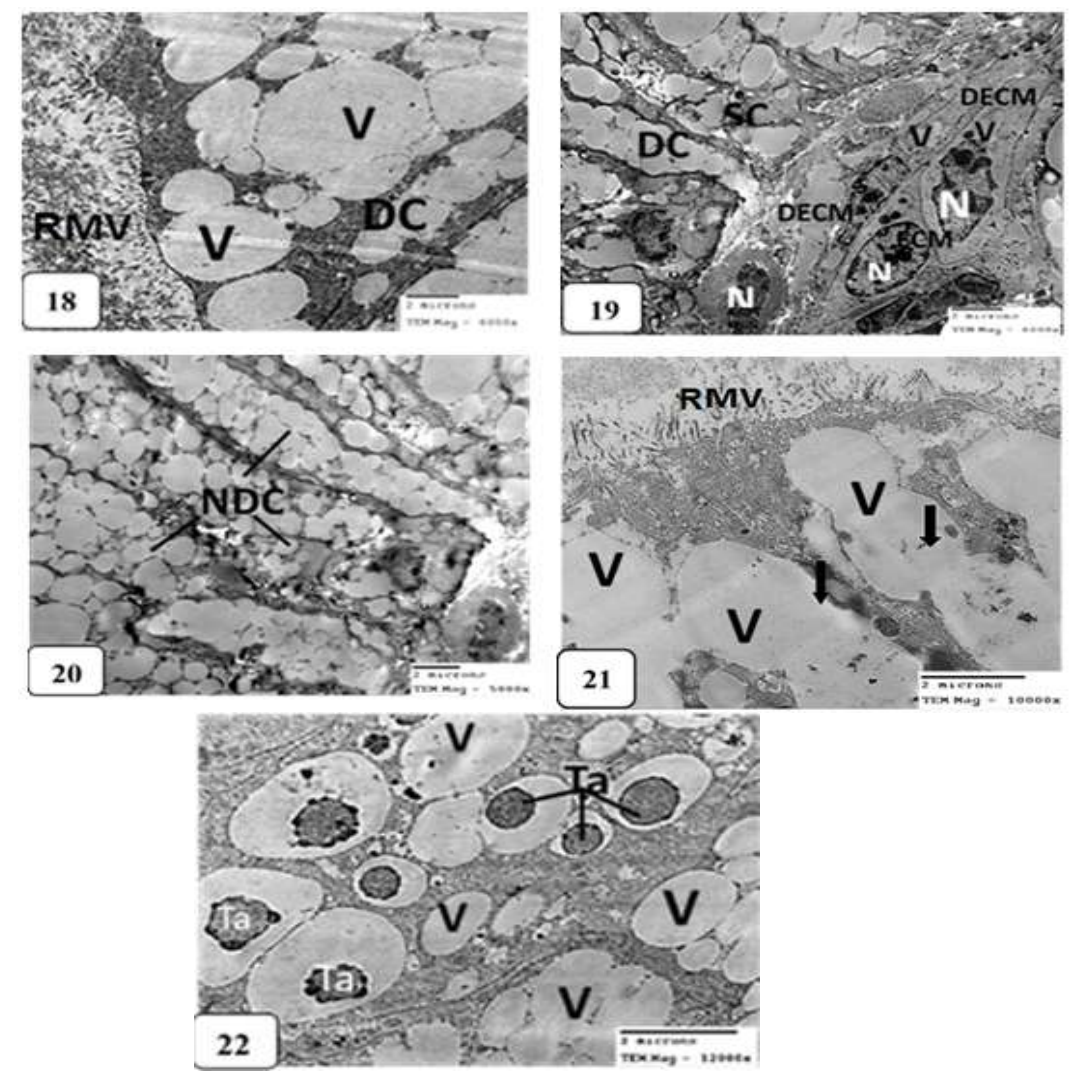

Figures 18-22: TEM of sections in the digestive gland of treated $L$. maximus with $\mathrm{LC}_{90}$ of thymol compound.

Fig. 18: Showing digestive cell (DC), rupture of microvilli (RMv) and numerous vacuoles of various sizes $(X=6000)$. Fig. 19: Showing normal small vacuoles $(V)$, beside degenerated extracellular matrix (DECM) (X=6000). Fig. 20: Showing nearly necrosis of digestive cells (NDC), after disappearing of nucleus and majority of cellular organelles $(X=5000)$. Fig. 21: Showing fused-wide vacuoles and (V) rupture of microvilli (RMv) and nearly necrosis of two types of cells $(X=10000)$. Fig. 22: Showing numerous vacuoles of various sizes $(\mathrm{V})$, toxic agents $(\mathrm{Ta})$ inside the cells and nearly necrosis of two types of cells $(X=12000)$. 


\section{DISCUSSION}

The giant garden slug Limax maximus, tiger slug or great grey slug, is belonging to family Limacidae (Gaitán-Espitia, et al., 2012). The present results of morphological features and anatomy of the internal organs of L. maximus are agree with results of Beltagi, et al. (2016).

Histological inspection of the normal digestive gland of L. maximus confirms the existence of two main cell types namely: digestive and secretory cells. Digestive gland was reported to be composed of two cell types: digestive and excretory or secretory cell by both Abdel-Haleem (2013) in L. maximus and Ibrahim (2006) in Biomphalaria alexandrina. In contrary, Zaldibar, et al. (2007) described two cell types; digestive and basophilic cells in the digestive gland of the snails Eobania vermiculata and Littoria littorea. However, Morten (1979) described three types of cells; digestive, calcium and thin cells in the slug Deroceras caruanae. In addition, the digestive gland had been revealed that it consists of three types of cells; digestive, calcium and excretory cells by Lopes, et al., (2001) in the land snail Oxychilus atlanticus, Chabicovsky, et al. (2004) in land snail Helix pomatia, Abo Bakr (2011) in land snail E. vermiculata, Sharaf, et al. (2015) in land snail Helicella vestalis and Mustafa and Awad, (2018) in the slug Lehmannia marginata. Moreover, four cell types: digestive, calcium, excretory and thin cells were found in E. vermiculata by Hamed, et al., (2007).

The present histological results of the digestive gland of thymol-treated L. maximus with $\mathrm{LC}_{50}$ and $\mathrm{LC}_{90}$ for $48 \mathrm{hrs}$. are similar and agree with the reported results of Abo Bakr (2011) and Yousef (2011), as well as with results of Hamed, et al., (2007) in the same gland of treated land snail E. vermiculata with methomyl pesticide in spate of they found four cells: digestive, calcium, excretory and thin cells.

The present cytoplasmic vacuolation and degeneration of secretory cells in the digestive acini of treated L. maximus are in accordance with results of Abdel-Haleem (2013) in the same species, who used plant extracts of three plants Euphorbia splendens, Ziziphus spina-Christi and Ambrosia maritimaon against two freshwater snails B. alexandrina and B. truncates, and agree with Saad, et al. (2012) in the treated snail $B$. alexandrina with extracts of two plants Cestrum diurnum and Casimiroa edulis. In addition, Sharaf, et al. (2015) observed additional histological changes in the digestive gland of treated land snail $H$. vestalis with methiocarb and chlorpyrifos-pesticides included; severe tubular disruption, nuclear pyknosis and necrosis of tubules. Moreover, Mustafa (2018) reinforced the present results in another gland, salivary gland, where he found vacuolated cytoplasm and degenerated nuclei after treated with $\mathrm{LC}_{90}$ of thymol against $L$. maximus.

Ultrastructural inspection of the normal digestive gland of L. maximus confirms the existence of two main cell types namely: the digestive cells and secretory cells. These results fit well with Aly (2007) in the same species. On the contrary, Nath, et al. (2015) found that the digestive gland of the slug, Laevicaulis alte is composed of digestive cell, excretory cell and calcium cell.

The present ultrastructural results on treated target slugs agree with finding of Hamed, et al. (2007), who found severe cytoplasmic vacuolation, accumulation of residual bodies or yellow granules and reduction in microvilli of the digestive gland of the land snail E. vermiculata treated with methomyl, topically or by poison baiting technique. In addition, the present findings agree with Abdel-Haleem (2013) in the freshwater snails $B$. alexandrina and $B$. truncates treated with the Egyptian plant 
extracts E. splendens, Z. spina-Christi and A. maritimaon, who found cytoplasmic vacuolation, swelling of secretory cell and accumulation of residual bodies.

\section{REFERENCES}

Abdel-Haleem, A. A. and EI-Kassas, N. B. (2013). Ultrastructure and histopathological effects of some plant extracts on digestive gland of Biomphalaria alexandrina and Bulinus truncates. The Journal of Basic \& Applied Zoology, 66 (2): 27-33.

Abo Bakr, Y. (2011). Histopathological changes induced metaldehyde in Eobania vermiculata (Müller 1774). Alexandria Science Exchange J., 32 (3): 300-310.

Aly, R. H. (2007). The ultrastructure of the digestive gland of the slug Limax maximus. Egyptian Journal of Zoology, 48: 241-255.

Azzam, K. M. (1995). Studies on some malacophagous insects in Egypt. Ph.D. Thesis, Fac.Agric.Cairo.Uni.

Beltagi, S.; Mustafa, O. and Hussam, G. (2016). Further anatomical studies on the great slug Limax maximus (linnaeus1758) 1st record living in Touch Kalyobya province - near Cairo - Egypt. African J. Biol. Sci., 12 (1): 125-138.

Chabicovsky, M.; Klepal, W. and Dallinger, R. (2004). Mechanisms of cadmium toxicity in terrestrial pulmonates: programmed cell death and metallothionein overload. Environ. Toxicol. Chem., 23(3): 648-655.

El-okda, M. M. K. (1980). Land snails of economic importance on vegetable crops at Alexandria and neighboring region. Agric. Res. Rev., 58(1): 79-84.

El-Zemity, S. R.; Mohamed, S. A.; Radwan, M. A. and Sherby, S. M. (2001). Molluscicidal efficacy and repellency of some naturally occurring monoterpenoids against the land snail, Helix aspera, Muller (Mollusca: Pulmonata). Annals of Agricultural Science-Cairo, 46(1): 339-346.

Ferreira, P.; Soares, G. L. G.; Davila, S. and Bessa, E. C. D. A. (2009). The influence of caffeine and thymol on the survival, growth and reproduction of Subulina octona (Bruguier, 1789) (Mollusca: Subulinidae). Brazilian Archives of Biology and Technology, 52(4): 945-952.

Finney, D. J. (1971). Probit Analysis. $3^{\text {rd }}$ Edition, Cambridge University Press, Cambridge.

Gaitán Espitia, J. D.; Franco, M.; Bartheld, J. L. and Nespolo, R. F. (2012) Repeatability of energy metabolism and resistance to dehydration in the invasive slug Limax maximus. Invertebrate Biology, 131(1): 11-18.

Grodnitzky, J. A. and Coats, J. R. (2002). Qsar evaluation of monoterpenoids' insecticidal activity. Journal of Agricultural and Food chemistry, 50(16): 45764580.

Hamed, S. S.; Abdel meguied, N. E.; Essawy, A. E.; Radwan, M. A. and Hegazy, A. E. (2007). Histological and ultrastructural changes induced by two carbamate molluscicides on the digestive gland of Eobania vermiculata. J. Biol. Sci., 7(6): 1017-1037.

Herbert, D.G. (2010). The introduced terrestrial Mollusca of South Africa. SANBI Biodiversity Series 15 . South African National Biodiversity Institute, Pretoria.

Ibrahim, A. A. (2006). Studies on terrestrial molluscs in some Delta governorates. Ph.D. Thesis. Agric. Zool. \&Nematology. Dept. Fac. Agric., Al-Azhar Univ., Egypt. 
Koziowski, J. and Koziowska, M. (2007). New possibilities for protecting plants against harmful slugs (Gastropoda: Pulmonata). Fragmenta Agronomica., 24: 245-251.

Litchfield, J. T. J. and Wilcoxon, F. (1949). A simplified method of evaluating doseeffect experiments. Journal of pharmacology and experimental therapeutics, 96(2): 99-113.

Lopes, M.; Rodrigues, A. and marigomes, I. (2001). morphology and histology of the digestive gland of oxychilus (Drouetia) atlanticus (morelet \& drouet) (Gastropoda: Pulmonated). Arquipelago, Life \& Mar. Sci., 2(B): 71-76.

Morten, B. (1979). The diurnal rhythm and the cycle of feeding and digestion in the slug Deroceras caruanae. J. Zool. (London), 87: 135-152.

Mustafa, O. M. (2001). Biological, histological and physiological Studies on the slug Limax maximus of economic important in Egypt. ph. D. Thesis. Zoology Dept. Faculty of Girls for Arts, Science \&Education, Ain Shams Univ.

Mustafa, O. M. (2018). Effects of a plant product (Thymol) on the salivary gland of the giant slug Limax maximus in Egypt (Histological and Ultrastructural study). Egyptian journal of Aquatic Biology and Fishers, 22(3): 55-59.

Mustafa, O. M. and Awad, I. R. (2018). studies on the histology, histochemistry and ultrastructure of the digestive gland of the slug lehmannia marginata (Gastropoda: pulmonata). Egypt. J. Zoo1., 69: 43-53.

Nath, T. K.; Sao, Sh. and Misra, K. K. (2015). Ultrastructure of digestive gland cells of an estuarine slug, Laevicaulis alte from Sundarban coast of India. International Journal of Research in Zoology, 5(2): 21-28.

Pavela, R., and Sedlák, P. (2018). Post-application temperature as a factor influencing the insecticidal activity of essential oil from Thymus vulgaris. Industrial Crops and Products, 113: 46-49.

Saad, A. A.; Aly, R. H.; Ragab, F. M. A. and Abdel-wareth, M. T. A. (2012). Effect of Cestrum diurnum and Casimiroa edulis Plants on the digestive gland and its related enzymes in the freshwater snail Biomphalaria alexandrina. Toxicol. Environ. Health. Sci. 4(2): 109-114.

Sharaf, H. M.; Salama, M. A. and Abd El-Atti, M. S. (2015). Biochemical and histological alterations in the digestive gland of the land snail Helicella vestalis (Locard, 1882) exposed to Methiocarb and Chlorpyrifos in the laboratory. J. Cytol. Histol., 6 (3): 334-343.

Singh, K. and Singh, D. K. (2000). Effect of different combinations of MGK-264 or piperonyl butoxide with plant-derived molluscicides on snail reproduction. Archives of environmental contamination and toxicology, 38(2): 182-190.

Sokolik, C. G.; Ben-Shabat, B. R.; Gedanken, A. and Lellouche, J. P. (2018). Proteinaceous microspheres as a delivery system for carvacrol and thymol in antibacterial applications. Ultrasonics sonochemistry, 41: 288-296.

Thiengo, S. C.; BARBOSA, A. F.; Coelho, P. M. and Fernandez, M. A. (2005). Moluscos exóticos com importância médica no Brasil. Departamento de Malacologia, Instituto Oswaldo Cruz, Fundação Oswaldo Cruz,1-14.

Thomas, S. (2013). Medicinal use of terrestrial molluscs (slugs and snails) with particular reference to their role in the treatment of wounds and other skin lesions. Journal of worldwide wounds.

Yousef, H. N.; Beltagi, S. M. H.; Al-Shinawy, M. S. A. and Elkattan, N. A. (2011). Effect of certain plant products on some physiological and histological aspects of the terrestrial snail, Eobania vermiculata, in Egypt. Ph. D. Thesis, Zoology Dept. Fac. Edu., Ain Shams Univ. 
Zaldibar, B.; Cancio, I.; Soto, M., and Marigómez, I. (2007). Digestive cell turnover in digestive gland epithelium of slugs experimentally exposed to a mixture of cadmium and kerosene. Chemosphere, 70(1): 144-154.

\section{ARABIC SUMMARY}

" Limax maximus " التغيرات النسيجية والتركيبية الدقيقة في الغدة الهضمية للبزاقة المصرية thymol التي تم معالجتها بمركب الثيمول التباتي المضاد للرخويات، مع التنويه بار اسات بيولوجية التيول معية

يوستينا ناصر توفيق حبيب ـ أحمد عبد السلام عبد الحليم ـ أميمة محمد مصطفى - إيمان حسن إسماعيل.

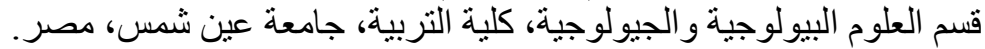

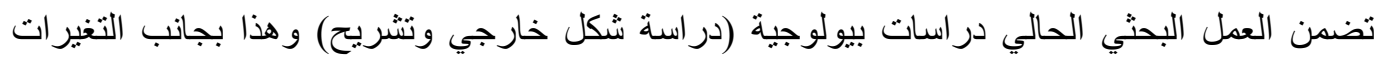

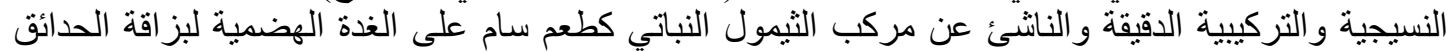

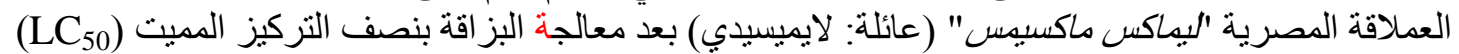

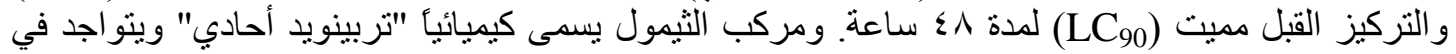

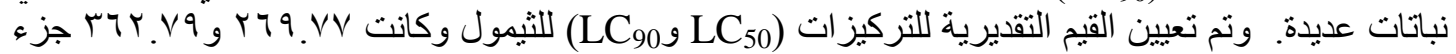
في المليون على التو الي. وتأثير LC

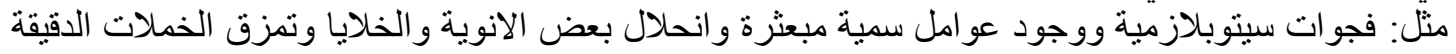

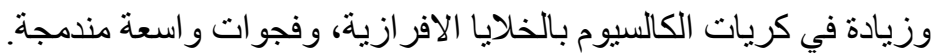

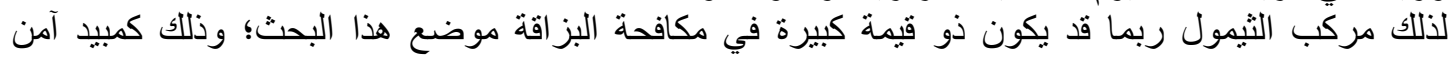
و اقتصادي للرخويات دون التسبب بضرر للنظام البيئي المحيط، وذللك بدلا من استخدام مبيدات آفات كيميائية الني باستطاعنها أن تحدث تلوث للبيئة. 